\title{
Placental lactogen production and functional differentiation of rat trophoblast cells in vitro
}

\author{
M. J. Soares and S. R. Glasser* \\ Department of Physiology, Ralph L. Smith Mental Retardation, Research Center, University of \\ Kansas Medical Center, Kansas City, Kansas 66103, and *Department of Cell Biology, \\ Baylor College of Medicine, Houston, Texas 77030, U.S.A.
}

\begin{abstract}
Summary. Cells from the labyrinth region of the developing rat chorioallantoic placenta were able to differentiate in vitro into cells capable of producing placental lactogen. Progesterone selectively inhibited placental lactogen production by labyrinth cell cultures undergoing differentiation but had no apparent effect on lactogen production by mature trophoblast giant cells. The measurement of placental lactogen production is a useful method for monitoring the functional differentiation of rat trophoblast cells in vitro.
\end{abstract}

\section{Introduction}

One of the specific endocrine functions of the rat placenta is the production of placental lactogens (Kelly et al., 1975; Robertson et al., 1982; Soares et al., 1985). At least two placental lactogens, possessing distinct biochemical characteristics, are produced during the development of the choriovitelline and chorioallantoic placentas of the rat (Soares et al., 1985). The production of placental lactogen-1, a high molecular weight protein, coincides with the predominance of the choriovitelline placenta (midgestation), whereas placental lactogen-2, a low molecular weight protein, coincides with the predominance of the chorioallantoic placenta (second half of gestation). Soares et al. (1985) reported that the choriovitelline and chorioallantoic placentas contributed to the production of both types of placental lactogen. Trophoblast giant cells are components of the choriovitelline and chorioallantoic placentas and are capable of producing both types of placental lactogen (Soares et al., 1985).

To understand better the ontogeny of placental lactogen production in the chorioallantoic placenta we have investigated the behaviour of trophoblast cells isolated from the primordia of the placental labyrinth and compared them with the behaviour of mature trophoblast giant cells. Several reports have demonstrated morphological differentiation of the mouse chorioallantoic placenta after transplantation to extrauterine sites (Kirby, 1964; Carr, 1977, 1979; Rossant \& Ofer, 1977; Tutton \& Carr, 1984) and after culture in vitro (Ilgren, 1981; Johnson \& Rossant, 1981; Rossant \& Tamura-Lis, 1981) but no one has reported differentiation of functional indices of the chorioallantoic placenta. We have therefore examined the functional differentiation of trophoblast cells isolated from the primordia of the placental labyrinth.

\section{Materials and Methods}

\footnotetext{
Animals, dissection of embryos, and trophoblast cell cultures. Adult Sprague-Dawley rats were obtained from TIMCO breeders (Houston, TX), and SASCO breeders (Omaha, NE). The rats were kept in a light schedule of $14 \mathrm{~h}$ light and $10 \mathrm{~h}$ darkness (lights on at 07:00 h) and had unrestricted access to food and water. Female rats were housed with Sprague-Dawley male rats and checked every morning for the presence of a copukatory plug (designated Day 1 of pregnancy).
} 
Embryos with their encapsulating decidual tissue (conceptuses) were dissected from the uteri of rats on Day 13 of pregnancy. Conceptuses were then dissected with the aid of a dissecting microscope $(\times 10-20$ magnification). The tissues were collected into and washed with Hank's balanced salt solution without $\mathrm{Ca}^{2+}$ and $\mathrm{Mg}^{2+}$. Decidual tissue encapsulating each embryo was removed with fine forceps. Chorioallantoic trophoblast giant cells were separated from the underlying labyrinth by gentle teasing with 21 -gauge needles according to the procedure of Jenkinson \& Owen (1980). This is not an absolutely clean separation in that there are labyrinth cells that remain with the chorioallantoic trophoblast giant cells; however, the underlying labyrinth tissue is devoid of any giant cells. Choriovitelline trophoblast giant cells adherent to Reichert's membrane were isolated with fine forceps from the remaining conceptus (Soares et al., 1985). Trophoblast giant cells from both regions were further enriched by enzymically treating them with a neutral protease (Dispase, grade II; Boehringer Mannheim Biochemicals, Indianapolis, IN). Trophoblast giant cell explants from 15-20 embryos were placed into a $15-\mathrm{ml}$ conical tube containing $5 \mathrm{ml}$ of the protease solution $\left(4.8 \mathrm{mg} / \mathrm{ml}\right.$ phosphate-buffered saline, PBS). The conical tube was then placed into a $37^{\circ} \mathrm{C}$ water bath and gently agitated for $10-15 \mathrm{~min}$. At the end of the incubation the cells were gently disrupted by aspiration with a Pasteur pipette. The cells were then allowed to settle by gravity for 2-3 min, the buffer removed, and the cells resuspended with PBS. This washing and resuspension procedure was repeated three times. The buffer was finally aspirated and $8 \mathrm{ml}$ NCTC-109 culture medium (M. A. Bioproducts, Walkersville, MD) supplemented with $10 \%$ heat-inactivated fetal calf serum (Grand Island Biological Company, GIBCO, Grand Island, NY), penicillin (100 units/ml; GIBCO), streptomycin $(100 \mu \mathrm{g} / \mathrm{ml}$; GIBCO), and L-glutamine $(135.7 \mu \mathrm{g} / \mathrm{ml})$ were added. The cells were evenly suspended and apportioned into four $35 \times 10 \mathrm{~mm}$ dishes $(2 \mathrm{ml} / \mathrm{dish})$. Culture dishes were placed in an incubator with a controlled environment of $95 \%$ air $/ 5 \% \mathrm{CO}_{2}$ at $37^{\circ} \mathrm{C}$. The enzymic treatment effectively releases the contaminating cells which do not sediment as rapidly as the trophoblast giant cell aggregates. Explants from the labyrinth area of the chorioallantoic placenta, free of trophoblast giant cells, were treated enzymically as described above. Instead of the settling procedure, the dissociated cells were centrifuged at $200 \mathrm{~g}$ for $5 \mathrm{~min}$. The remainder of the procedure was identical to that described for the trophoblast giant cells.

The culture media were changed at 48 -h intervals. Spent culture media were stored frozen at $-20^{\circ} \mathrm{C}$ for later analysis. The cultures were ended after 10 days. The cells were then solubilized in extraction buffer $(0 \cdot 5 \mathrm{ml} / \mathrm{dish}$; $0.05 \mathrm{M}$-Tris, pH $7.0,8 \mathrm{M}$-urea, $1 \%$ sodium dodecyl sulphate, $0.01 \%$ phenylmethylsulphonyl fluoride (PMSF), $1 \%$ $\beta$-mercaptoethanol), precipitated with $2 \mathrm{ml} 20 \%$ trichloroacetic acid, incubated for $1 \mathrm{~h}$ at $4^{\circ} \mathrm{C}$, and centrifuged at $2000 \mathrm{~g}$ for $20 \mathrm{~min}$. The pellets were dissolved in $0 \cdot 1 \mathrm{~N}-\mathrm{NaOH}$, heated at $90^{\circ} \mathrm{C}$ for $20 \mathrm{~min}$, and centrifuged at $2000 \mathrm{~g}$ for $20 \mathrm{~min}$. The protein content of the supernatants was determined by the method of Lowry et al. (1951). Each experiment was conducted with a minimum of 3 replicates and repeated 3 times.

Histological examination of trophoblast cells. Trophoblast giant cell and labyrinth cell cultures were established as described above except that the cells were plated on glass coverslips placed in the bottom of $35 \times 10 \mathrm{~cm}$ culture dishes. The cultures were terminated at various intervals during the culture period, fixed in $3 \%$ formalin-phosphate buffered saline ( $\mathrm{pH} \mathrm{7.0)}$, stained with haematoxylin and eosin and mounted on glass slides. The slides were examined by light microscopy and representative areas were photographed.

Progesterone effects on production of placental lactogen. These were determined by the addition of progesterone at a concentration of $10^{-6} \mathrm{M}$ in a vehicle of ethanol to trophoblast giant cells and labyrinth cells to cultures. The ethanol content of the culture media never exceeded $0.02 \%$. Control cultures received the same concentration of the vehicle. For these experiments the culture media were changed at $24-h$ intervals. The cultures were ended after 4 days. These are conditions previously shown to be effective for the mouse (Soares \& Talamantes, 1985). In an additional experiment we examined the effects of different progesterone concentrations on the production of placental lactogen by cultured labyrinth cells. For this experiment, the culture medium was changed at 48 -h intervals for a 10-day cuiture period. The remainder of the protocol was similar to that described above. Each experiment was conducted with a minimum of 3 replicates and repeated 3 times.

Measurements of placental lactogen. The placental lactogen was measured with a prolactin radioreceptor assay. The assay was a modification of the procedure originally described by Shiu et al. (1973). Briefly, the prolactin receptor source was liver membranes obtained from late pregnant rats according to the technique of Posner et al. (1974). Ovine prolactin (NIAMDD-oPRL-15) was used for radioiodination and as a reference standard. Radioiodination was accomplished with the solid-phase radioiodination reagent, IODO-GEN (Pierce Chemical Company, Rockford, IL), as described by Markwell \& Fox (1978). The radioiodinated hormone was purified by gel filtration on Sephadex G-100 (column dimensions: $0.9 \times 20 \mathrm{~cm}$; Pharmacia Fine Chemicals, Piscataway, NJ). The specific activity of the radioiodinated ovine prolactin ranged from 30 to $50 \mu \mathrm{Ci} / \mu \mathrm{g}$. The buffer for the assay was $25 \mathrm{~mm}-\mathrm{Tris}-\mathrm{HCl}, \mathrm{pH} 7.6$, containing $10 \mathrm{~mm}^{-\mathrm{CaCl}_{2}}$ and $0.5 \%$ bovine serum albumin. The remainder of the procedure was similar to the procedure developed by Shiu et al. (1973). The sensitivity of the assay was $0.25-0.5 \mathrm{ng} / \mathrm{tube}$.

Placental lactogen was measured directly from the spent culture media or gel filtration fractions without any prior treatment. The content of placental lactogen in the Day 13 tissues, used for the cell cultures, was determined after homogenization in $50 \mathrm{~mm}$-Tris- $\mathrm{HCl}$ buffer, $\mathrm{pH} 8.2$, containing $0.1 \mathrm{M}-\mathrm{NaCl}$ and $1 \mathrm{mM}-\mathrm{PMSF}$. The homogenate was centrifuged at $3000 \mathrm{~g}$ for $20 \mathrm{~min}$ and supernatant fractions were stored at $-20^{\circ} \mathrm{C}$ until assayed. The tissues were not subjected to the enzymic cell dispersion. Two trophoblast giant cell explants or labyrinth primordia were used per determination and 12 separate determinations were performed on tissue obtained from 6 female rats.

Gel fltration chromatography. Media from the labyrinth cultures were fractionated by column chromatography on Sephadex G-100 (Pharmacia) to determine the type of lactogen produced by the cells (Soares et al., 1985). The 
dimensions of the column were $1.5 \times 92 \mathrm{~cm}$ and the elution buffer was $0 \cdot 1 \mathrm{M}-\mathrm{NH}_{4} \mathrm{HCO}_{3}-0 \cdot 1 \mathrm{M}-\mathrm{NaCl}, \mathrm{pH} 7 \cdot 8$. Elution fractions $(2.5 \mathrm{ml})$ were analysed with the prolactin radioreceptor assay. The loading volumes for the chromatography experiments were 1.5-2 ml. Each chromatography experiment was repeated at least 3 times. Placental lactogen-1 has a characteristic $\mathrm{V}_{\mathrm{e}} / \mathrm{V}_{\mathrm{o}}=1.5$ and placental lactogen-2 has a characteristic $\mathrm{V}_{\mathrm{e}} / \mathrm{V}_{\mathrm{o}}=2.1$ in this system (Soares et al., 1983; Soares et al., 1985).

Statistical analysis. Placental lactogen output by the trophoblast cultures was analysed by analysis of variance with repeated measures (Keppel, 1973). The source of variation from significant F-ratios was determined with Dunn's Multiple Comparison test (Keppel, 1973).

\section{Results}

The labyrinth cell cultures were devoid of any discernible trophoblast giant cell contamination on the day the cultures were set up and after 24 hours of culture. Giant cells were clearly present on Day 4 and became more prominent by Day 6 of culture (Fig. 1).
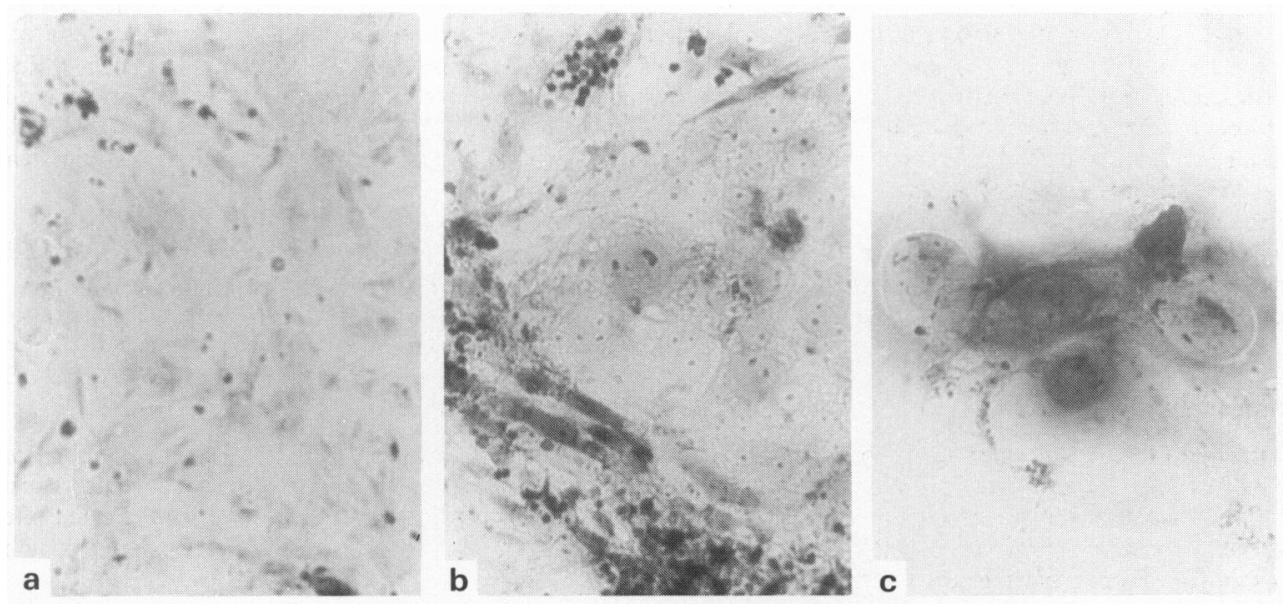

Fig. 1. (a) Labyrinth cells from the 1st day of culture, (b) giant cells present in labyrinth cultures from the 6th day of culture, and (c) giant cells present in the choriovitelline trophoblast giant cell cultures from the 2 nd day of culture. $\times 200$.
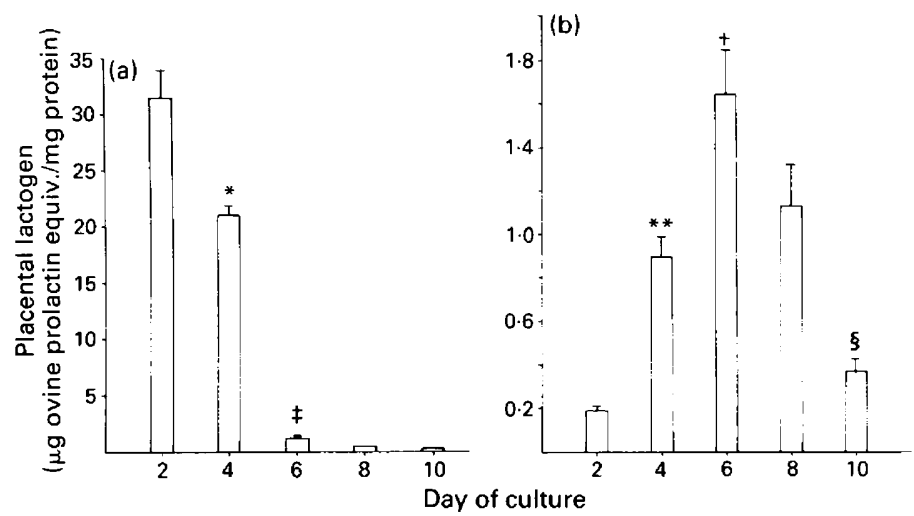

Fig. 2. In-vitro placental lactogen secretion by (a) choriovitelline trophoblast giant cells and (b) labyrinth cells isolated from Day 13 rat embryos. Each bar represents the mean measurement from 6 dishes. ${ }^{*} P<0.05$ compared with value on Day 2 of culture, ${ }^{* *} P<0.01$ compared with value on Day 2 of culture, $\dagger P<0.05$ compared with value on Day 4 of culture, $\ddagger P<0.01$ compared with value on Day 4 of culture, $\S P<0.01$ compared with value on Day 6 of culture. 
At the time of dissection the content of placental lactogen in trophoblast giant cells isolated from the choriovitelline and chorioallantoic placentas was $1052.4 \pm 58.4 \mathrm{ng} / \mathrm{mg}$ tissue protein and $465.3 \pm 26.5 \mathrm{ng} / \mathrm{mg}$ tissue protein, respectively. Trophoblast giant cells isolated from the choriovitelline or chorioallantoic placentas produced placental lactogen. The cells showed a gradual decline in lactogen production over the 10-day culture period (Fig. 2a). Lactogen output decreased significantly from Day 2 to Day 4 of culture and again from Day 4 to Day 6 . The pattern

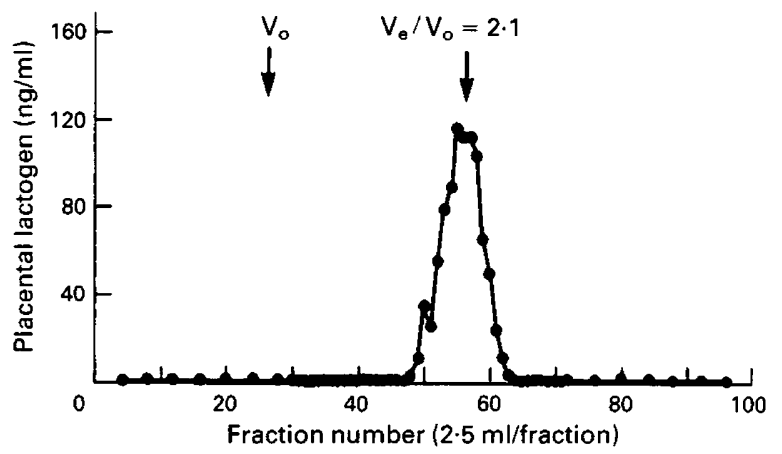

Fig. 3. An elution profile of incubation medium from labyrinth cells on the 4 th day of culture (48-h collection period). These profiles were obtained by gel filtration chromatography on Sephadex G-100. The activity of the eluates was monitored with the prolactin RRA. A similar profile was observed when incubation media were obtained on the 6th day of culture.

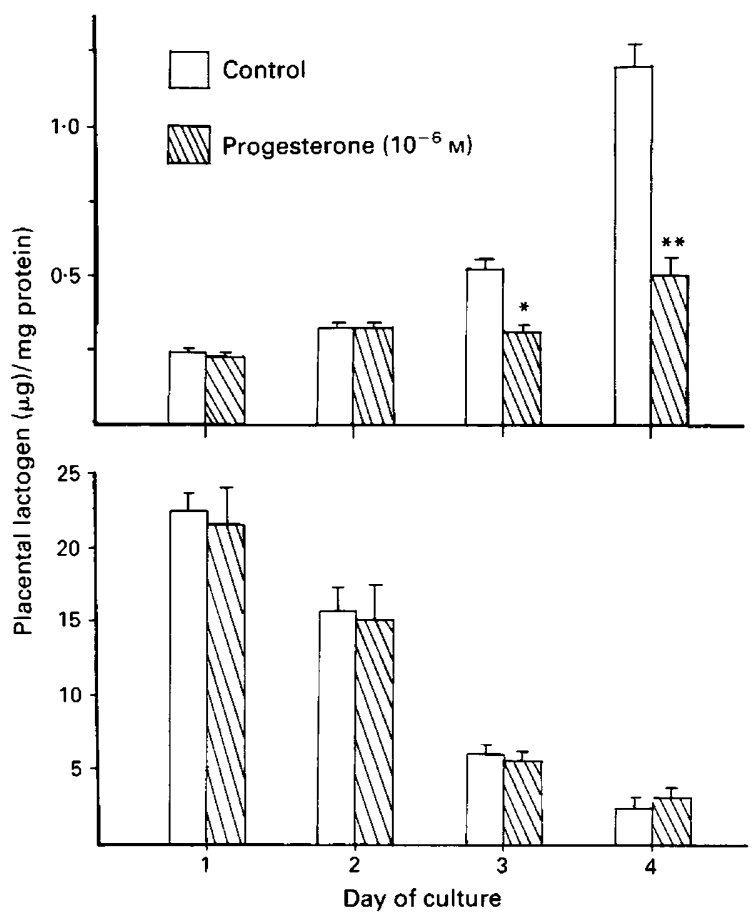

Fig. 4. Effects of progesterone on placental lactogen production by (a) labyrinth cells and (b) trophoblast giant cells. Each bar represents the mean \pm s.e.m. measurement from 6 dishes. ${ }^{*} P<0.05$ compared with control value on Day 3 of culture, ${ }^{* *} P<0.01$ compared with control value on Day 4 of culture. 
of placental lactogen release during the culture period was similar for the choriovitelline (Fig. 2a) and chorioallantoic (data not shown) trophoblast giant cells.

At the time of dissection the content of placental lactogen in the labyrinth cells was very low (13.0 $\pm 0.99 \mathrm{ng}$ lactogen $/ \mathrm{mg}$ tissue protein, or $3.7 \pm 0.3 \mathrm{ng}$ lactogen/labyrinth, $n=12$ ). Cells from the labyrinth region showed minimal output of lactogen during the first 2 days of culture (Fig. 2b). The production of placental lactogen increased significantly from Day 2 to Day 4 of culture, peaked on Day 6, and decreased significantly by Day 10 of culture. The output of lactogen on Day 6 cf culture represented an 8-fold increase from the output on Day 2 and over a 100 -fold increase from the initial content in the labyrinth at the time of dissection. The labyrinth cells produced exclusively the low molecular weight form, placental lactogen-2 (Fig. 3).

Exposure of the labyrinth cells to progesterone significantly inhibited the output of placental lactogen on Days 3 and 4 of culture (Fig. 4). Progesterone did not significantly affect the output by trophoblast giant cells isolated from the choriovitelline placenta (Fig. 4). The effect of progesterone was concentration-dependent, with a concentration of $0.25 \mu \mathrm{M}$ proving to be the minimum effective dose examined (Table 1). In this experiment placental lactogen production in the control cell cultures increased about 7-fold from Day 2 to Day 8 of culture.

Table 1. Effects of progesterone concentration on the release of placental lactogen by labyrinth cells during a 48-h interval between Days 6 and 8 of culture

\begin{tabular}{lccccc}
\hline $\begin{array}{l}\text { Progesterone conc. }(\mu \mathrm{M}) \\
\begin{array}{l}\text { Placental lactogen release } \\
(\mu \mathrm{g} / 48 \mathrm{~h} / \mathrm{mg} \text { tissue protein) }\end{array}\end{array}$ & 0 (control) & 0.1 & 0.25 & 1.0 & 2.5 \\
\hline
\end{tabular}

Values are mean \pm s.e.m. Each value represents the mean measurement from 8 dishes.

*Values significantly different from control values, $P<0.01$.

†Values significantly different from each other, $P<0 \cdot 01$.

\section{Discussion}

Cells from the labyrinth region of the developing rat chorioallantoic placenta have the ability to differentiate in vitro into cells capable of producing placental lactogen. The labyrinth cells were isolated on Day 13 of gestation and initially contained minimal amounts of lactogen. Placental lactogen production increased progressively during the first 6 days the labyrinth cells were cultured. At the beginning, no 'giant cells' were observed in the labyrinth cultures, but by Day 4 of culture distinct 'giant cells' were apparent. The appearance of 'giant cells' and increased placental lactogen production may or may not be causally related. A detailed immunocytochemical analysis during the in-vitro differentiation period is greatly needed but will have to await the availability of antiserum to rat placental lactogen-2.

Cotte et al. (1980) have reported that cytotrophoblast cells, isolated from human placentas of early gestation, undergo morphological and functional changes in culture consistent with the formation of syncytial trophoblast cells. Similarly, sheep trophoblast cells differentiate in vitro, showing an increase in placental lactogen production concomitant with the formation of binucleate cells (Steven et al., 1980). Binucleate cells are the source of lactogen in the sheep placenta (Martal et al., 1977; Reddy \& Watkins, 1978; Watkins \& Reddy, 1980; Wooding, 1981) and syncytial trophoblast cells are the source of lactogen in the human placenta (see Hoshina et al., 1985, for a review). These in-vitro differentiation processes appear to occur readily in serum-supplemented culture medium without the addition of any special factors (Cotte et al., 1980; Ilgren, 1981; Rossant \& 
Tamura-Lis, 1981; present study). The ability of trophoblast precursor cells to differentiate in vitro is therefore a common feature shared by at least two species of rodents, a ruminant, and a primate.

Trophoblast giant cells produce two types of placental lactogens (Soares et al., 1985), which differ biochemically and according to their temporal appearance during gestation (see 'Introduction'). Trophoblast precursor cells isolated before Day 13 of gestation from blastocysts or the ectoplacental cone may differentiate in vitro into trophoblast giant cells capable of producing the high molecular weight lactogen, placental lactogen-1, that predominates at midpregnancy. Studies are currently in progress to answer these uncertainties.

The amounts of placental lactogen released by dissected trophoblast giant cells was considerably greater than the maximal amounts of placental lactogen released by differentiated labyrinth cells. This difference is undoubtedly related to the cellular composition of the cultures. The trophoblast giant cell cultures contained relatively few other cell types (non-trophoblast giant cells), whereas the differentiated labyrinth cultures were heterogeneous and contained a variety of cell types including syncytial trophoblast cells, trophoblast giant cells, and other unidentified cell types.

Soares \& Talamantes (1985) have shown that progesterone inhibits the production of placental lactogen by midpregnant mouse placental explants which contained trophoblast giant cells and trophoblast precursor cells. In the present study we have demonstrated that progesterone selectively inhibited placental lactogen production by cultures undergoing differentiation but had no apparent effect on lactogen production by mature trophoblast giant cells. Since trophoblast giant cells are capable of producing progesterone (see Sherman, 1983, for a review), then this modulatory action of progesterone may be seen as a negative feedback regulation of the formation of new placental lactogen-secreting cells. Additionally, the progesterone concentrations used in these experiments may not be unphysiological. The proximity of the trophoblast giant cells to the developing labyrinth cells may enable effective concentrations of progesterone to be reached. Although it is uncertain at present whether progesterone is a physiological regulator of labyrinth cell production of placental lactogen, the findings, nonetheless, may be of use for manipulating trophoblast cell behaviour in vitro.

We thank Dr A. Parlow and the National Institute of Arthritis, Diabetes and Digestive and Kidney Diseases for providing ovine prolactin; JoAnne Julian for helpful discussion and technical assistance; and Greta Kirk, Janice Swinton, and Linda Carr for help with the paper. This work was supported by NIH grants HD-17147 and HD-07495 to S.R.G. M.J.S. was supported by a National Research Service Award postdoctoral fellowship, HD-06363; an NIH Biomedical Research Support Grant, S07 RR05373; and by a grant from the University of Kansas Cancer Center and the American Cancer Society, ACS IN-115.

\section{References}

Carr, D.H. (1977) An experimental study of trophoblast growth in the lung. Obstet. Gynecol. 50, 473-478.

Carr, D.H. (1979) Trophoblast growth in the lungs of mice. Obstet. Gynecol. 54, 461-466.

Cotte, C., Easty, G.C., Neville, A.M. \& Monaghan, P. (1980) Preparation of highly purified cytotrophoblast from human placenta with subsequent modulation to form syncytiotrophoblast in monolayer cultures. In Vitro 16, 639-646.

Hoshina, M., Boothby, M., Hussa, R., Pattillo, R., Bamel, H.M. \& Boine, I. (1985) Linkage of human chorionic gonadotropin and placental lactogen biosynthesis to trophoblast differentiation and tumorigenesis. Placenta 6, 163-172.

Ilgren, E.B. (1981) On the control of the trophoblastic giant cell transformation in the mouse: homotypic cellular interactions and polyploidy. J. Embryol. exp. Morph. 62, 183-202.

Jenkinson, E.J. \& Owen, V. (1980). Ontogeny and distribution of major histocompatibility complex (MHC) antigens on mouse placental trophoblast. J. Reprod Immunol. 2, 173-181. 
Johnson, M.H. \& Rossant, J. (1981) Molecular studies on cells of the trophectodermal lineage of the postimplantation mouse embryo. J. Embryol. exp. Morph. 61, 103-116.

Kelly, P.A., Shiu, R.P.C., Robertson, M.C. \& Friesen, H.G. (1975) Characterization of rat chorionic mammotropin. Endocrinology 96, 1187-1195.

Keppel, G. (1973) Design and Analysis. Prentice-Hall, Englewood Cliffs.

Kirby, D.R.S. (1964) The 'invasiveness' of the trophoblast. In The Early Conceptus, Normal and Abnormal, pp. 68-73, Ed. W. W. Park. Churchill Livingstone, London.

Lowry, O., Rosebrough, N., Farr, A. \& Randall, R. (1951) Protein measurement with the Folin phenol reagent. J. biol. Chem. 193, 265-275.

Markwell, M.A.K. \& Fox, C.F. (1978) Surface-specific iodination of membrane proteins of viruses and eucaryotic cells using 1, 3, 4, 6-tetrachoro-3 $3,6 \alpha$ dephenylglycoluril. Biochemistry, N.Y. 17,4807-4817.

Martal, J., Djiane, J. \& Dubois, M.P. (1977) Immunofluorescent localization of ovine placental lactogen. Cell Tiss. Res. 184, 427-433.

Posner, B.I., Kelly, P.A., Shiu, R.P.C. \& Friesen, H.G. (1974) Studies of insulin, growth hormone and prolactin binding: tissue distribution, species variation and characterization. Endocrinology 95, 521-531.

Reddy, S. \& Watkins, W.B. (1978) Immunofluorescence localization of ovine placental lactogen. $J$. Reprod. Fert. 52, 173-174.

Robertson, M.C., Gillespie, B. \& Friesen, H.G. (1982) Characterization of the two forms of rat placental lactogen (rPL): rPL-I and rPL-II. Endocrinology 111, 1862-1866.

Rossant, J. \& Ofer, L. (1977) Properties of extraembryonic ectoderm isolated from post-implantation mouse embryos. J. Embryol. exp. Morph. 39, $183 \cdots 194$.
Rossant, J. \& Tamura-Lis, W. (1981) Effect of culture conditions on diploid to giant cell transformation in postimplantation mouse trophoblast. J. Embryol. exp. Morph. 62, 217-227.

Sherman, M.I. (1983) Endocrinology of rodent trophoblast cells. In Biology of Trophoblast, pp. 401-467. Eds Y. W. Loke \& A. Whyte. Elsevier, Amsterdam.

Shiu, R.P.C., Kelly, P.A. \& Friesen, H.G. (1973) Radioreceptor assay for prolactin and other lactogenic hormones. Science, N.Y. 180, 968-971.

Soares, M.J. \& Talamantes, F. (1985) Placental lactogen secretion in the mouse: in vitro responses and ovarian and hormonal influences. J. exp. Zool. 234, 97-104.

Soares, M.J., Colosi, P., Ogren, L. \& Talamantes, F. (1983) Identification and partial characterization of a lactogen from the midpregnant mouse conceptus. Endocrinology 112, 1313-1317.

Soares, M.J., Julian, J.A. \& Glasser, S.R. (1985) Trophoblast giant cell release of placental lactogens: temporal and regional characteristics. Devl Biol. 107, 520-526.

Steven, D.H., Mallon, K.A. \& Nathanielsz, P.W. (1980) Sheep trophoblast in monolayer cell culture. Placenta 1, 209-221

Tutton, D.A. \& Carr, D.H. (1984) The fate of trophoblast retained within the oviduct in the mouse. Gynecol. Obstet. Invest. 17, 18-24.

Watkins, W.B. \& Reddy, S. (1980) Ovine placental lactogen in the cotyledonary and intercotyledonary placenta of the ewe. J. Reprod. Fert. 58, 411-414.

Wooding, F.B.P. (1981) Localization of ovine placental lactogen in sheep placentomes by electron microscope immunocytochemistry. J. Reprod. Fert. 62, $15-19$. 